NOGUEIRA, Marco Aurélio. O encontro de Joaquim Nabuco com a política: as desventuras do liberalismo. São Paulo: Paz e Terra, 2010.

\title{
A coerência de Nabuco
}

The coherence of Nabuco

Ademir Luiz da Silva ${ }^{1}$

Um historiador que se torna objeto de sua matéria é sempre digno de nota. O pai Heródoto foi tanto historiador quanto história. Jules Michelet, Edward Gibbon e Leopold von Ranke, de fato e de direito, dividem a mesma honra. Joaquim Nabuco também. Nascido em 19 de agosto de 1849, no Recife, Joaquim Aurélio Barreto Nabuco de Araújo tornou-se um dos mais importantes intelectuais públicos da segunda metade do século XIX e início do XX, no Brasil. Dono de vários talentos, consagrou-se como político, diplomata, jornalista, jurista, historiador etc. Líder abolicionista, estilista literário admirado, orador brilhante, membro fundador da Academia Brasileira de Letras, seu aniversário foi escolhido para marcar uma data em nosso calendário cívico, por força da Lei ${ }^{\circ} 12.130$ de 17 de dezembro de 2009, o Dia Nacional do Historiador. Ideia do senador Cristóvão Buarque, sancionada pelo vice-presidente da República José Alencar. O primeiro, um político intelectual; o segundo, um empresário político. Bastante conveniente, em se tratando da memória afetiva do homenageado.

Em 2010 se comemora o centenário da morte de Joaquim Nabuco, ocorrida em Washington, EUA, no dia 17 de janeiro de 1910. Apesar da importância histórica do personagem, as celebrações foram tímidas. Alguns breves pronunciamentos em Brasília, algumas palestras universitárias, algumas páginas na imprensa, um ou outro breve documentário sendo exibido em redes públicas de televisão, nada muito além do usual em se tratando de celebridades do passado. Famosíssimo em seu tempo, na atualidade Nabuco não provoca muito interesse no grande público. Tornouse matéria para iniciados, estudiosos ou eruditos.

Diferentemente, por exemplo, dos Estados Unidos, onde estadistas de alta estatura, como Lincoln, Jefferson e Roosevelt, são homenageados diuturnamente em classes da pré-escola, no Brasil tratamos de colocá-los

\footnotetext{
${ }^{1}$ Doutor em História pela Universidade Federal de Goiás; docente da Universidade Estadual de Goiás. Correio eletrônico: ademir.hist@ bol.com.br
} 
em um discreto limbo. Não são totalmente esquecidos, nem devidamente lembrados. Preenchemos nosso imaginário histórico com figuras farsescas como D. João VI ou sujeitas a galhofas, como D. Pedro I. Tipos refinados ao estilo de Nabuco, José Bonifácio ou Rui Barbosa dificilmente caem nas graças do "homem cordial" que habita ao sul do equador, terra onde, diria Sérgio Paulo Rouanet, só é pecado parecer elitista.

Em meio às poucas homenagens ao centenário de morte de Nabuco, uma se destaca. O lançamento, pela editora Paz e Terra, da segunda edição, revista e ampliada, de As desventuras do liberalismo - Joaquim Nabuco, a monarquia e a república, do sociólogo e cientista político Marco Aurélio Nogueira, professor livre-docente pela Universidade Estadual Paulista UNESP. Lançado originalmente em 1984, o livro ganhou um novo título: $O$ encontro de Joaquim Nabuco com a política: as desventuras do liberalismo. Como a ordem dos fatores não altera o produto, o nome de Nabuco vindo no título ou no subtítulo não compromete em nada a excelência da obra. Talvez explique melhor seu objetivo, submetendo certa visão do liberalismo ao personagem principal e não o inverso, como estava na primeira edição. $\mathrm{O}$ liberalismo brasileiro do século XIX não se resume a Nabuco, embora Nabuco seja fundamental para compreender suas "desventuras" no país.

Esse encontro de Nabuco com a política não trata meramente da política partidária, da troca de favores e tráfico de influência; trata da política em seu sentido mais amplo, em seu sentido aristotélico. A política, para Aristóteles, é uma ciência prática, uma forma de buscar o conhecimento como meio de ação. Dividiu-a em ética, na felicidade individual do cidadão, e na busca pela felicidade coletiva por meio da formação de instituições capazes de provê-la. Nabuco encaixa-se perfeitamente nesse arquétipo: foi um erudito e, ao mesmo tempo, um homem de ação, preocupado com os rumos tomados pelas instituições da imensa pólis Brasil.

No breve prefácio original, da década de 1980, republicado nessa segunda edição, o jurista Raymundo Faoro escreveu que

Marco Aurélio Nogueira, sempre fiel ao encanto de Joaquim Nabuco, viu na sua incursão abolicionista uma aventura liberal. Lembra, a esse propósito, a jornada do cavaleiro andante, numa aproximação que diz e sugere (p.16). 
A descrição é certeira. Não que o autor seja leniente com Nabuco, blindando-o de críticas. Longe disso. Mas percebe, e deixa clara, sua consciência dos méritos do homem ímpar com o qual está lidando. Se, por um lado, trata Nabuco como um cavaleiro andante idealista, um homem que acreditou no e lutou pelo Brasil, por outro, mostra-o como um deslocado, uma pérola jogada aos porcos. Talvez um cavaleiro andante ao estilo Dom Quixote, excluindo-se aqui o físico risível e a ingenuidade absoluta do tipo de Cervantes. Um Quixote sóbrio, ciente de que está lutando contra moinhos de ventos, identificáveis como na velha política do atraso que comando o Brasil desde sempre, tão bem trabalhada pelo próprio Faoro, em Os donos do poder.

Nesse sentido, no prefácio à segunda edição, Cristóvão Buarque lamenta que

[...] fomos capazes de substituir o Imperador por Presidente, mas não construímos uma Nação Republicana. Nabuco sempre colocou a realidade à frente da superficialidade e, por isso, além de razões de sua psicologia aristocrática, ele parece contraditório aos nossos olhos republicanos (p. 12).

Essa contradição, ou aparente contradição, que marca a trajetória de Nabuco, de progressista no Império a conservador na República, é o grande tema do livro. Sua esfinge. Nogueira contrapõe-se à tese recorrente de múltiplos Nabuco, defendida por nomes como Celso Uemori e Jeffrey Needell. Para ele, "existiu sempre um mesmo e único personagem, portador de um liberalismo suficientemente elástico para acompanhar as mudanças históricas sem perder coerência" (p. 19-20).

Nogueira organizou sua obra em quatro capítulos e uma conclusão. Os títulos são bastante didáticos. O primeiro é "Texto e contexto: o autoritarismo disfarçado", seguido de "Na vanguarda da revolução burguesa: Nabuco abolicionista". O terceiro é "O cavaleiro andante: do abolicionista ao monarquista" e o quarto "O caminho de volta: diplomacia, patriotismo, República". Segue-se, finalmente, "Conclusão: liberalismo, liberalismos". Apesar da lógica cronológica, não se trata de uma biografia. É um livro de tese: Nogueira deseja provar um ponto de vista. Preocupa-se pouco em apresentar a vida particular de Nabuco. Seu objetivo é trabalhar ideias. Os elementos biográficos surgem para contextualizá-las, num amplo processo de reconstrução da trajetória de um intelectual. 
Merece destaque, por exemplo, a abordagem de Nogueira acerca da relação entre Nabuco e seu pai, o senador José Thomaz Nabuco de Araújo. Não há sombra do tom freudiano que, muitas vezes, assombra os comentários sobre a evidente influência paterna sobre o filho, que o levou a escrever a obra-prima Um estadista do Império. Se esse livro é apologético, na verdade Nabuco louva sua estirpe e, por conseguinte, a si mesmo, não apenas seu pai. O que ambos testemunharam, viveram e construíram durante o Império, tanto em Um estadista do Império quanto em Minha formação, não é pano de fundo para a história oficial, mas resulta em exemplos da revolução burguesa no Brasil.

Vitorioso na campanha abolicionista, chegando a ser testemunha da assinatura da Lei Áurea, em 1888, Nabuco precisou se reinventar após a Proclamação da República. Monarquista convicto, foi relegado ao ostracismo nos primeiros anos do novo regime. Fez seu último discurso no Parlamento em 1889, pouco antes de 15 de novembro. Em seguida, retirouse para Petrópolis, onde se dedicou a escrever. Entre 1893 e 1899 produziu seus textos seminais: o relato de sua formação intelectual e a biografia de seu pai. Não são escritos de um aposentado prestando contas ao passado, mas obras de um autor altamente dotado, no auge da maturidade, e com muitos planos. Nabuco desejava voltar à vida pública. Encontrou no prestígio que seguia recebendo, por conta de sua produção intelectual, um caminho. Foi bem sucedido, visto que, no governo de Campos Salles, seria convidado a defender o Brasil num litígio contra a Inglaterra, referente a territórios na Amazônia, e depois nomeado embaixador do Brasil em Washington. Sempre esteve à vontade na arena das ideias, onde podia cooptar, pelo convencimento retórico, até mesmo o adversário político da véspera.

Chama atenção o fato de Nogueira ter analisado seu personagemtítulo a partir do viés marxista, usando categorias estabelecidas por Gyorgy Lukács e, principalmente, Antonio Gramsci. Nabuco é apresentado ao leitor como sendo um representante do grupo dos intelectuais orgânicos. Para justificar-se, Nogueira cita Gramsci quando, em seus Cadernos do cárcere, o pensador italiano define os intelectuais orgânicos como "uma ou mais camadas intelectuais que lhe dão homogeneidade e consciência da própria função, não apenas no campo econômico, mas também no social e político" (Gramsci, apud NOGUEIRA, 2010, p. 25). Seria esse o Nabuco abolicionista. 
Porém, convém lembrar que a teoria gramsciana também aponta o intelectual orgânico como servidor do capital: "o empresário capitalista cria junto de si o técnico industrial, o especialista em economia política, os organizadores de um novo sistema legal etc". Essa categoria intelectual está longe de ser formada por reis-filósofos, infinitamente sábia e moralmente incorruptível, conforme propôs, como ideal, Julien Benda, em seu tratado $A$ traição dos intelectuais. Ao contrário: são empregados, que vendem sua inteligência e poder de argumentação, da mesma forma com que os trabalhadores braçais vendem sua força física. Citando Edward Said, em Representações do intelectual,

Gramsci acreditava que os intelectuais orgânicos estão ativamente envolvidos na sociedade; isto é, eles lutam constantemente para mudar mentalidades e expandir mercados; ao contrário dos professores e dos clérigos, que parecem permanecer mais ou menos no mesmo lugar. $^{2}$

Portanto, segundo o pensador italiano, não haveria idealismo na atuação dessa categoria intelectual. Mas o Nabuco abolicionista não foi um idealista, ainda que um idealista com os pés muito bem plantados no chão?

Felizmente, essa armadilha teórica é bem resolvida no texto. Da mesma forma que Emma Rothschild, em Sentimentos econômicos, provou que Marx e Adam Smith eram bem mais próximos do que se poderia supor, Nogueira esmerou-se ao longo do livro em mostrar que o ideário liberal de Nabuco incorporava, sem maiores traumas, elementos do pensamento socialista francês e do trade-unionism inglês. Ao mesmo tempo, sua militância abolicionista não admitia agitação e propaganda radical advinda das ruas, era fundamentalmente parlamentar. Não adianta tentar encontrar em Nabuco sombra de um "Irmão do Quilombo". O legalismo marcou sua atuação. Ainda que, "diante do Imperador, a tática abolicionista se desdobrava em três: reconhecia seu papel decisivo, atuava para separá-lo do escravismo e criticava sua relutância" (p. 172).

No Brasil, a figura do Imperador e o Império, o monarca e a monarquia, eram indissociáveis. Apesar das críticas, Nabuco admirava D.Pedro II. O homem, o governante e, sobretudo, o intelectual. Como é

\footnotetext{
${ }^{2}$ SAID, Edward W. Representações do intelectual. São Paulo: Companhia das Letras, 2005. p. 20.
} 
amplamente reconhecido, em nível teórico o Imperador era contra o sistema escravista, considerava-o uma prática bárbara. Não o extinguia para não se prejudicar politicamente, não perder o apoio dos latifundiários. O que de fato ocorreu após o 13 de Maio. Nabuco, em certo sentido, apreciava o ritmo imperial, o ritmo da tradição e da paz, lento e constante. Acreditava que a abolição viria, ainda que demorasse. A aprovação das leis Eusébio de Queiróz, de 1850, do Ventre Livre, em 1871, e dos Sexagenários, em 1885, eram a maior prova do avanço gradual.

Sua maior crítica aos republicanos era quanto à sua pressa. Desprezava o desejo de substituir a paz monárquica por uma inovação irresponsável, pretensamente moderna: "Destruir um governo que tem dado os mais admiráveis resultados para pôr em lugar dele uma teoria, é ausência de senso prático". Considerava o positivismo e o jacobinismo no Brasil meros pastiches político-filosóficos. Num primeiro momento, Nogueira define como curioso o "alinhamento de Nabuco com os civilistas republicanos". Em seguida, estabelece que aquele grande homem do século XIX teria, finalmente, entrado no XX, percebendo que a República traria mudanças estruturais, ordem e estabilidade. Afirmou em sua correspondência: "por isso chamaram-me na Monarquia republicano e por isso fiquei na República monarquista” (p. 312). Rendeu-se ao lema da ordem e do progresso, sem deixar de ser quem sempre foi: o coerente Nabuco. 